\title{
LA RENTA DE LA TIERRA EN LEON \\ DURANTE LA EDAD MODERNA. \\ PRIMEROS RESULTADOS \\ Y ALGUNAS REFLEXIONES \\ A PARTIR DE FUENTES MONASTICAS
}

\author{
JOSE A. SEBASTIAN AMARILLA \\ Universidad Complutense
}

\section{Introducción}

Como es sabido, los pagos anuales, efectuados mayoritariamente en especie, que multitud de campesinos debían satisfacer por el acceso temporal al usufructo de espacios de cultivo, conformaban una de las magnitudes más significativas para el devenir de la agricultura y, en general, de la vida económica de la Corona de Castilla durante el Antiguo Régimen. Al respecto, pueden aducirse varios motivos, de todos conocidos, estrechamente vinculados entre sí.

a) Primero, obviamente, el notable número de cultivadores sobre los que recaía la citada obligación y la amplitud de la superficie de labor que la sustentaba, variables ambas que, como hoy se admite comúnmente, tendieron a aumentar entre fines del siglo $\mathrm{xv}$ y las primeras décadas del $\mathrm{xIx}{ }^{1}$. El porcentaje del 30 por 100 , asignado por el llamado Censo de Godoy a los activos agrarios españoles que, en 1797 , recibían el apelativo de arrendatarios, esconde contrastes apreciables. Así, en la Submeseta Norte, dicha proporción ascendía al 41 por 100 , y en provincias como Salamanca, Soria y León rebasaba el 50 por $100^{2}$. En lo que hace al segundo aspecto, es lícito relacionar, aunque existiesen excepciones, el patrimonio rústico de las clases privilegiadas y la extensión de terreno explotada indirectamente ${ }^{3}$. Si, de un lado, en las 22 provincias castellanas catastradas a mediados del Setecientos, el 14,7 por 100 del territorio resultó perteneciente a individuos e institutos eclesiásticos, Campomanes, en una estimación de la que se hace eco Fernández de

1 Angel Garcia Sanz (1985), pp. 650-651.

2 José Canga Argüelles (1833), t. II, p. 33. Ello sin considerar que no eran pocos los labradores propietarios que solían redondear sus explotaciones tomando a renta otros predios.

${ }^{3}$ Sobre la gestión directa por parte de una comunidad monacal de una hacienda respetable, José Miguel López García (1986), pp. 132 y 302 y ss. No debían ser muchos, sin embargo, los terratenientes que, como en este caso, aprovechaban directamente el 40 por 100 de sus dominios. 
Pinedo ${ }^{4}$, afirmaba que al menos la mitad del monto restante, propio de laicos, era de titularidad nobiliaria; ello situaría cerca del 60 por 100 del total al volumen de tierra propiedad de privilegiados. En tierras leonesas existen indicios que apuntan a proporciones aún más elevadas: si en la comarca de la Bañeza, únicamente respecto a labrantíos y prados, es posible que clérigos y nobles controlasen cerca del 53 por 100 de los mismos, en el Oriente leonés sólo los tonsurados, sobre una muestra de 80 términos, poseían el 34 por 100 del espacio total ${ }^{5}$.

b) En consonancia con lo anterior, las rentas generadas por sus heredades configuraban una de las formas señeras - la principal en no pocos casos- de participación en el producto agrario de los propietarios y, por ende, fundamentaban una parte sustancial de sus ingresos monetarios. La creciente complejidad que afectó desde el siglo xv a la composición de la renta feudal de la aristocracia castellana, sobre todo de los más altos linajes, que hallaron una fuente de ingresos trascendental en las rentas reales enajenadas, no impidió que el arrendamiento de sus haciendas continuase proporcionando entradas de consideración, de la mayor importancia para la nobleza de segunda fila ${ }^{6}$. Entre los terratenientes eclesiásticos, los regulares siempre dependieron en gran medida de las mismas, mientras que para los seculares, en especial para cabildos catedralicios y mitras, los diezmos solían ser el elemento decisivo de su recibo?.

c) Las cuantías obtenidas, generalmente en especie, por la cesión del usufructo de fincas ubicadas en dominios caracterizados por su dispersión, eran centralizadas por los propietarios o por sus administradores, constituyendo cada año un abultado volumen de cereales, buena parte del cual - junto al percibido por diezmos - alimentaba el comercio de éstos y estaba en disposición de subvenir de modo significativo al sostenimiento de las aglomeraciones urbanas ${ }^{8}$. En lo que a la provincia de León se refiere, sin que la com-

4 Emiliano Fernández de Pinedo (1980), p. 55.

5 Para La Bañeza, Laurcano M. Rubio Pérez (1987), pp. 220-221. Para el Oriente leonés, elaboración propia a partir de AHN, Hacienda, Mapas Generales del Catastro, letra D, libs. 7454, 7459, 7505, 7506 y 7507.

- Bartolomé Yun Casalilla (1987), pp. 124 y ss. y 330 y ss.; Angel García Sanz (1977), pp. 338-361, y (1988), y Pedro Ruiz Torres (1989).

- Sirva como ejemplo el de la leonesa Abadía de Sandoval, la cual obtuvo, por término medio, entre 1569 y 1835 , el 63 por 100 de sus ingresos en metálico mediante la comercialización de los granos allegados merced a las rentas estipuladas por la cesión temporal de su acervo rústico; $\mathrm{AHN}$, Clero, Libros de Caxa, 5168, 5169, 5174, 5175, 5176 y 5177. En cambio, tanto el obispo como el cabildo de la Catedral de Segovia, en la segunda década dél siglo xIx, lograban más del 90 por 100 de sus entradas en dinero de los diczmos que recaudaban - Angel García Sanz (1977), pp. 348 y 350-. En lo que atañe a los ingresos del obispo segoviano, Maximiliano Barrio Gonzalo (1982) ha llegado a una conclusión análoga para todo el siglo Xvirr.

- Interesantes aportaciones acerca de la participación de perceptores de rentas y diez. 
paración entrañe afirmación alguna sobre el auténtico destino de los contingentes aludidos, piénsese que únicamente los conventos y monasterios desamortizados en 1835 en la misma recibían anualmente, sólo en concepto de rentas, cerca de 23.000 fanegas de granos, mientras que las necesidades anuales de la capital leonesa, el principal núcleo urbano de aquélla, rondaban por entonces las 80.000 fanegas de trigo, cebada y centeno ${ }^{9}$.

d) Para la mayoría de los llevadores de tierras en renta, exceptuando quizá a los grandes arrendatarios que contrataban jornaleros y a los «señores medianeros», especialistas en el subarriendo, la mencionada exacción, verificada comúnmente sobre el producto bruto y carente de la proporcionalidad respecto del nivel de las cosechas típica del diezmo, era seguramente la obligación anual más onerosa. Multitud de explotaciones caampesinas, especialmente entre las situadas al Norte del Sistema Central, tenían en las variaciones de la renta su piedra de toque, pudiendo éstas, tanto mejorar sus expectativas de futuro como poner en tela de juicio su viabilidad. De ahí la enorme importancia de la citada variable, su capacidad, ora para favorecer la extensión de las roturas y el aumento de la producción agríco'a, como ocurrió en muchas zonas castellanas durante las tres primeras décadas del siglo xviII, ora para resultar un factor de autofrenado de dichos avances, como se ha diagnosticado para el último tercio de la misma centuria ${ }^{10}$, ora para coadyuvar a crisis de notable intensidad, como aconteció en diversas áreas de la Cuenca del Duero a fines del siglo XvI".

e) Por último, la renta abonada por la explotación de tierras ajenas debe considerarse como la expresión más genuina del entramado de relaciones económicas y sociales vigente en el campo castellano durante el Antiguo Régimen. Los prolegómenos de su establecimiento, en el marco de unas negociaciones en las que un innegable elemento de modernidad _la búsqueda

mos en la comercialización de los granos y en el abastecimiento de las ciudades pueden encontrarse en Gonzalo Anes (1970), pp. 327 y ss.; Angel García Sanz (1977), pp. 172 y ss.; Concepción de Castro (1987), pp. 79 y ss., y José Luis Escrivá y Enrique Llopis (1989), pp. 117-124. Los conflictos habidos entre el cabildo catedralicio de Zamora y los regidores de la ciudad sobre los modos, momentos y precios a los cuales vendía dicha corporación religiosa sus excedentes de áridos dan idea de la importancia que éstos tenían, especialmente en tiempos de penuria, para el abasto de pan de la urbe; José Antonio Al. varez Vázquez (1987), pp. 100-181.

${ }^{2}$ AHN, Hacienda, leg. 4797(A), Contaduría de Rentas y Arbitrios de Amortización, "Estado del $n .^{\circ}$ de fincas asi rusticas como urbanas que posehian los Conventos y Monasterios de las Ordenes suprimidas en esta provincia, al tiempo de la formacion de los respectivos Inventarios, y de los cuales se posesiono la Amortización, con expresion de su cabida, renta y demas requisitos prevenidos por la Direccion general del ramo en 21 de octubre 1837», y Pascual Madoz (1845-50, cito por la edición facsímil por provincias de 1983), p. 188 del volumen correspondiente a León.

10 Angel García Sanz (1985), pp. 650-651, y Alberto Marcos Martín (1988), p. 23.

"Así lo indica Bartolomé Yun Casalilla (1985), p. 8, para la Tierra de Campos; por mi parte, he podido comprobarlo para el Oriente leonés. 
de un precio que equilibrase razonablemente las expectativas de rentabilidad de los poseedores y la precisión de disponer de tierra de labor de los potenciales arrendatarios- quedaba difuminado, no pocas veces, por el vigor de las relaciones personales preexistentes entre ambos grupos sociales, nunca simétricas, se manifestaban como la periódica reválida del privilegio de unos y de la voluntad de sobrevivencia de los otros. Es por ello que el importe anual finalmente concertado no resultaba sólo de la conjunción de variables como la oferta y la demanda de tierras, la trayectoria de los precios de los cereales y la de los efectivos poblacionales, ni tampoco únicamente de factores como el tamaño, calidad y situación de las fincas en cuestión; también dependía, y en no escaso grado, del origen, naturaleza y antigüedad de los vínculos que ligaban a los cultivadores con el aprovechamiento de aquéllas y con sus propietarios, $y$, asimismo, de las prerrogativas de otra índole que los últimos detentasen sobre los primeros. Así, entre quienes debían sufragar rentas y quienes gozaban del derecho de percibirlas, quedaba trazada una de las fronteras más decisivas que definían el mundo rural de la Castilla moderna.

A pesar de este carácter medular que la renta de la tierra poseía en el seno de la agricultura castellana del Antiguo Régimen, la reconstrucción seriada de testimonios cuantitativos sobre la misma no ha gozado de la asiduidad que, al efecto, han concitado otras magnitudes, como la producción agricola, las cotizaciones de los granos o ciertas variables demográficas ${ }^{12}$. Ello, lejos de resultar de una falta de interés por parte de los estudiosos, cabe achacarlo a la complejidad que, en comparación con las que conciernen a las aludidas, aqueja a sus fuentes documentales.

\section{Caracteristicas de las fuentes utilizadas}

Recurrir a los corpus documentales monásticos en busca de evidencias acerca del funcionamiento del sector agrario peninsular en el transcurso de los siglos XVI, XVII y XVIII no es, precisamente, una opción original ${ }^{13}$. La elección, en este caso, de los fondos de la abadía cisterciense de Santa María de Sandoval, ubicada a 14 kilómetros al Sudeste de León, también obedece a la bondad de una documentación que no se agota en un único tema ${ }^{14}$.

12 Estamos aún lejos de poder encarar estudios como el dedicado a este tema por Ricardo Robledo Hernández (1984) para el siglo XIX.

${ }_{13}$ Basta como ejemplo el de una reciente obra colectiva - Jean-Pierre Amalric y Pierre Ponsot (eds.) (1985) - en la que, de los doce trabajos presentados, ocho basan sus análisis en cifras extraídas de fuentes monacales.

${ }_{14}$ Fundamento de mi tesis doctoral, de pronta presentación, Agricultura y rentas monásticas en León. Santa Maria de Sandoval (116i-1835). Este monasterio dispuso durante 
Resultado de la estrategia adoptada por los monjes desde fines del siglo xv, consistente en la explotación indirecta de casi todas sus haciendas, los manuscritos referentes a la concertación, gestión y cobro de rentas incorporados al archivo claustral —custodiados hoy en el Archivo Histórico Nacionalson numerosos. Destaca, ante todo, un conjunto de más de 500 escrituras originales de cesión, cumplimentadas entre los decenios centrales del siglo XVI $\mathrm{y}$ los iniciales del $\mathrm{xIX}^{15}$. Junto a ellas, como complemento indispensable - pues, a pesar de su abundancia, no están exentas de lagunas para algunas propiedades y ciertas épocas-, deben consultarse otros documentos ${ }^{16}$. Conscientes de estos problemas, los padres archiveros más avisados procedieron a elaborar prontuarios de escrituras que recogiesen, para un período dado y una serie de haciendas, los extremos más importantes de los contratos acordados; de éstos ha sobrevivido uno inapreciable, el denominado Cuaderno de foros y arriendos antiguos de 1510 a $1540^{17}$. Posteriormente, en consonancia con el desarrollo de la contabilidad monacal, los compendios aludidos pasaron a formar parte, de modo más ordenado, seguramente desde 1552, de una de las piezas principales de la administración claustral, los Libros de Panera, gruesos volúmenes donde se anotaban, años tras año, todas las entradas y salidas de granos del cenobio. En efecto, hasta 1661, se incluyeron en los mismos los importes de las rentas que, anualmente, se ingresaban de todas y cada una de las heredades de la abadía ${ }^{18}$. Desde 1662 , sin embargo, los citados manuscritos pasaron a registrar únicamente el volumen global, percibido por razón de rentas, de cada especie cereal ${ }^{19}$.

la Edad Moderna de un patrimonio rústico que he podido evaluar en unas 4.225 Has., repartidas por 71 términos poblados y 14 despoblados, todos los cuales se hallaban situados en la franja oriental de la provincia de León que definen las montañas cantábricas por el Norte, el meridiano de la capital leonesa por el Oeste y la corriente del Cea, divisoria con la Tierra de Campos, por el Este y por el Sur.

is AHN, Clero, Escrituras de arrendamientos y foros, libs. 5196 y 5197 , y legs. 2753 , $2754,2755,2756,2757,2758,2760$ y 2761.

${ }_{10}$ Adviértase que la conservación de los contratos originales por parte de los regulares tenía como objetivo primordial disponer de antecedentes acerca de rentas y condiciones de cesión a la hora de renovar éstas. En lo que atañe a arrendamientos que, en su mayoría, no superaban los nueve años de duración, dicho interés, lógicamente, tendía a debilitarse con el paso del tiempo, favoreciendo su descuido. Amén de ello, y del simple extravío de papeles que no era habitual coser entre sí formando tomos, los propios bernardos aluden como motivo de pérdida la entrega de escrituras a abogados y procuradores para su presentación, con carácter de prueba, en pleitos litigados en corregimientos y chancillerías. Fuese por una o por otra razón, lo cierto es que resulta muy raro, por ejemplo, hallar contratos originales anteriores a mediados del siglo XVI.

${ }^{17}$ Cuyo expresivo subtitulo señala: «escrituras antiguas que faltan del archivo y hacen mucha falta»; AHN, Clero, leg. 2750.

${ }_{18} \mathrm{La}$ destrucción, en un incendio habido en la celda abacial en 1614, del primero de estos libros, el correspondiente al lapso 1552.1568 , nos priva de noticias de interés. Los restantes que adjuntan datos al respecto se hallan en AHN, Clero; Libros de Panera, 5190 (1569-1613), 5185 (1614-1638) y 5191 (1639-1717), hasta 1661, como queda dicho.

19 AHN, Clero, Libros de Panera, 5191 (1639-1717), desde 1662, y 5192 (1718-1835). 
Ello, empero, no entraña la pérdida total de la mencionada información, pues ya desde 1650 se había iniciado la redacción de otro tipo de documentos, los llamados Memoriales cobradores de granos $^{20}$. Estos recogen para cada hacienda un auténtico extracto del contrato de cesión vigente, comprendiendo nombres y vecindad de los renteros, cuantía de la renta, especies en que debía abonarse, fecha de la primera paga $\mathrm{y}$, con menos asiduidad, qué parte quedaba obligada a correr con el transporte de los áridos hasta la abadia.

Como puede colegirse, esta trilogía de testimonios integra un corpus documental de gran eficacia, tanto para el estudio de la evolución de las rentas como para el de las condiciones en las cuales éstas se concertaban ${ }^{21}$. Mientras que las escrituras originales informan, entre otras cosas, acerca de rentas acordadas y de plazos de cesión convenidos, los Libros de Panera y los Memoriales cobradores permiten contrastar dichos datos con las cantidades anuales verdaderamente satisfechas y con la auténtica duración de las cesiones, la cual, por mor de diversas circunstancias, podía variar respecto de la pactada. Los memoriales, no obstante, debido a lo transitorio de su uso y a sus propias características físicas, plantean el inconveniente de su falta para no poco períodos, como se observa en la nota 20. De todos modos, consienten comprobar, completar y, en su caso, corregir las noticias apor. tadas por los contratos originales.

\section{La trayectoria de la renta de la tierra en el Oriente leonés durante la Edad Moderna}

Consideramos en este apartado, principalmente, el conjunto de cifras que se recoge en el Apéndice 1 y se representa en el gráfico 1 , y que ilustra acerca de la evolución seguida por las rentas de heredades de pan llevar de Sandoval, percibidas en especie, entre 1569 y $1835^{22}$.

${ }^{20}$ Se trata de cuadernos cosidos con bramante, destinados a dotar a los monjes encargados de las cobranzas de un buen instrumento de control, que fueron confeccionados primero para lapsos de tres años y luego de cuatro, de conformidad con la duración de los abadiatos. He podido localizar $27-\mathrm{AHN}$, Clero, libs. 5151 y 5184 , y legs. 2751, 2752, 2754 y $2759-$, concernientes a los períodos $1650-51,1656-58,1659-61,1662-64,1665$, $1674-76,1686-88,1689-91,1698-1700,1721-23,1733-35,1735-38,1738-41,1742-45,1746-$ $1749,1750-53,1757-60,1767.70,1771-74,1779-82,1783-86,1795-98,1803-06,1807-10$, $1815-18,1819-23$ y $1833-36$.

${ }^{21}$ En mi opinión, dado que la mencionada evolución contable, propugnada por los padres visitadores de los cenobios designados por la congregación cisterciense, no fue exclu. siva de Sandoval, los fondos de los numerosos monasterios bernardos guardados en el Archivo Histórico Nacional, en la medida en la cual hayan sobrevivido completos, pueden incluir fuentes de gran valor para alcanzar los objetivos citados.

"2 La gran mayoría de las mismas se fijaba en pan mediado trigo y cebada, mantenién- 


\section{GRAFICO 1}

Rentas en grano obtenidas por Sandoval (1569-1835)

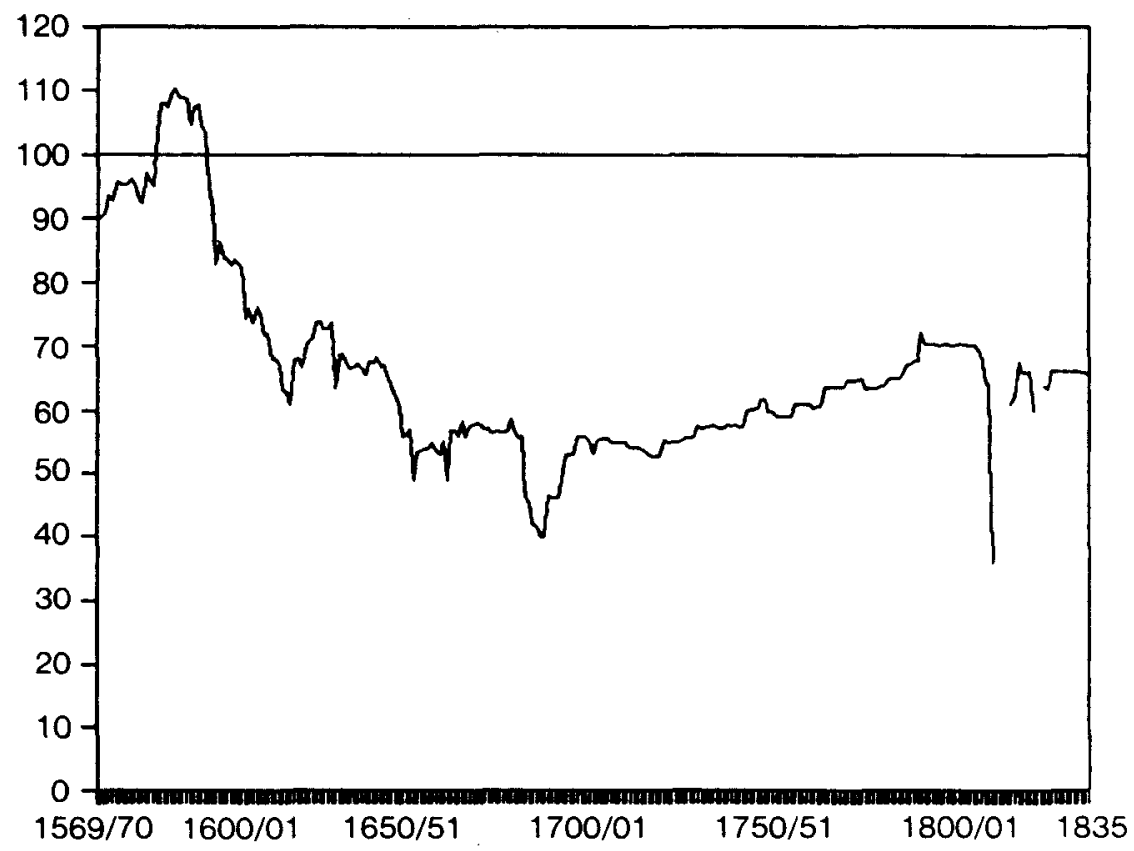

Números índice, base 100, 1569-1599

Como se aprecia en dicho gráfico, el movimiento de la renta, el cual, en vista del número de términos a los que incumbe (véase nota 14), cabe presumir representativo del concerniente al Oriente leonés, puede descomponerse en varias grandes etapas. En primer lugar, un siglo XVI caracterizado por el crecimiento de la magnitud aludida, del cual el perfil de la curva trazada sólo muestra el tramo final, aunque, eso sí, más notable. Felizmente,

dose su composición exacta sumamente estable en el transcurso del periodo analizado, a pesar de su notable longitud; así lo evidencian los siguientes cálculos:

\begin{tabular}{llllllllll}
\multicolumn{3}{c}{ Especies } & & & & $\begin{array}{c}\text { Promedio } \\
(1569-1835)(\%)\end{array}$ & & $\begin{array}{c}\text { Coeficiente } \\
\text { de variación }\end{array}$ \\
\hline Trigo & $\ldots$ & $\ldots$ & $\ldots$ & $\ldots$ & $\ldots$ & $\ldots$ & & 47,64 & \\
Cebada & $\ldots$ & $\ldots$ & $\ldots$ & $\ldots$ & $\ldots$ & & 42,90 & & 2,61 \\
Centeno & $\ldots$ & $\ldots$ & $\ldots$ & $\ldots$ & $\ldots$ & & 9,46 & & 14,53
\end{tabular}


para esta fase, es posible utilizar otros indicadores que, si bien provienen de información fragmentaria, resultan significativos.

a) La renta media anual de siete haciendas monásticas experimentó un exiguo crecimiento, del orden del 2,7 por 100 , entre $1510-1513$ y $1518-1528$; análogamente, otro conjunto, en este caso de 11 heredades, otorgó una renta media anual que no sólo no aumentó entre 1518-1528 y 1529-1537, sino que sufrió un ligero retroceso, exactamente del 0,6 por $100^{23}$. Así pues, parece plausible afirmar que, tras una época caracterizada por el alza de las rentas, como la segunda mitad del siglo $\mathrm{xv}$, éstas tendieron a estancarse durante las primeras décadas del Xvi en el ámbito que nos ocupa, lo cual coincidiría con lo detectado en la vecina Tierra de Campos ${ }^{24}$.

b) Si comparamos la renta media anual obtenida por una muestra de 14 heredades monacales en el intervalo 1510-1540, con la registrada en el período 1588-1593, observaremos un incremento del 33,9 por 100; éste, verificado con posterioridad a 1540 , como acabamos de ver, se operó a un ritmo mucho menos vivo entre dicha fecha y 1571 , que entre 1571 y $1590^{25}$.

\section{CUADRO 1}

Trayectoria de la renta de 14 fincas de Sandoval (1510-1593). Medias anuales en fanegas de todo pan

\begin{tabular}{|c|c|c|c|}
\hline Períodos & Media anual & Indice & $\begin{array}{c}\text { Tasa de crecimiento } \\
(\%)\end{array}$ \\
\hline $\begin{array}{llll}1510-1540 & \ldots & \ldots & \ldots \\
1569-1574 & \ldots & \ldots & \ldots \\
1588-1593 & \ldots & \ldots & \ldots\end{array}$ & $\begin{array}{l}1.920,7 \\
2.237,0 \\
2.572,0\end{array}$ & $\begin{array}{l}100,00 \\
116,47 \\
133,91\end{array}$ & $\begin{array}{l}0,49(1540-1571) \\
0,74(1571-1590)\end{array}$ \\
\hline
\end{tabular}

FuENTES: AHN, Clero, leg. 2750, Cuaderno de foros y arriendos antiguos de 1510 a 1540, y lib. 5190, Libro de Panera.

Como atestigua el gráfico 1, la cuantía máxima recaudada por los monjes por razón de rentas durante el Quinientos - y en el curso de todo el período considerado- se consiguió en $1590-4.634,9$ fanegas de áridos-, manteniéndose estancada a dicho nivel hasta 1.596 y cayendo luego.

${ }^{23}$ AHN, Clero, leg. 2750, Cuaderno de foros y arriendos antiguos de 1510 a 1540.

2. Bartolomé Yun Casalilla (1987), pp. 170 y ss.

${ }^{25}$ Las haciendas mencionadas son las de Villaverde de Sandoval, Mansillexa, Malateria, Santovenia, los cotos redondos de Palacino y Villamor, y las heredades de Fuentes de Carbajal, Jabares de los Oteros, Gusendos, Cubillas, Campo de Villavidel, Matanza, Roderos y Villamoros de Mansilla. 
El siglo que media entre 1596 y 1689 , como puede apreciarse, fue nefasto para el conjunto de rentas percibido por los bernardos de Sandoval, el cual acusó de forma particularmente grave la crisis planteada en la agricultura del Oriente leonés a fines del Quinientos y la posterior etapa depresiva. Precisamente uno de los factores que más contribuyeron al desencadenamiento de aquélla, merced a niveles tan abultados que cuestionaban la viabilidad de un buen número de explotaciones campesinas, fueron los desembolsos exigidos por el usufructo del terrazgo ${ }^{26}$.

Con sus valores más bajos consignados en el decenio de 1680 , lo que revela una notable sincronía entre la trayectoria de la renta de heredades de la abadía y las correspondientes a otras variables, como la producción agrícola y los efectivos demográficos de la zona, según se recogen en el gráfico $2^{27}$, pueden distinguirse diversos tramos en el seno de esta fase.

1) 1597-1621, caracterizado por una caída fortísima, casi vertical hasta 1601 y luego algo menos pronunciada, que situó a las rentas obtenidas en el último año indicado en una fracción igual al 60,8 por 100 del promedio recaudado entre 1569 y 1599.

2) 1622-1646, singularizado por una recuperación parcial, en parte frustrada por el brusco descenso de 163.3, y un posterior lapso de escasas varia. ciones que llevaron la proporción mencionada hasta el 66,9 por 100 en 1646.

3) 1647-1654, que albergó un nuevo retroceso de consideración, situándose el índice aludido, en la última fecha citada, en el 48,8 por 100 .

26 Para algunas haciendas monacales cuyos diezmos también pertenecian a los cistercienses, he podido estimar el producto bruto anual y calcular el porcentaje que, del mismo, significaba la renta en los últimos años del siglo xvi. Por término medio y para el decenio $1590-99$, dicha proporción alcanzaba el 23,6 por 100 en lo referente a las fincas de Fuentes de Carbajal, el 28,2 por 100 en el caso de las heredades de Matanza y nada menos que el 45,9 por 100 en lo atinente al coto monástico - heredades de Villaverde de Sandoval, Fontanilla, Malateria y Santovenia-; AHN, Clero, lib. 5190, Libro de Panera. Asimismo, respecto de las 14 propiedades citadas en la nota anterior, la renta media por unidad de superficie, en el lapso 1588-1593, se situó en 0,61 fanegas de grano por fanega arrendada - unos $1,18 \mathrm{Hl} / \mathrm{Ha}$ - - la cual, suponiendo un rendimiento factible de $1: 4$ por fanega de terreno en régimen de año y vez, equivaldría al 30,5 por 100 del producto bruto anual.

"2 Cuyas fuentes son: el Apéndice 1 para las rentas en especie, los diezmos de trigo allegados por Sandoval en seis localidades del territorio en cuestión, también consignados en los Libros de Panera del cenobio - AHN, Clero, libs. 5190, 5185, 5191 y 5192-, y el número de bautizados según una muestra integrada por cuatro parroquias de la zona - Santa María de Valduvieco, San Miguel de Valdesogo de Arriba y San Cipriano y San Andrés de Fuentes de Carbajal-, datos obtenidos en el Archivo Histórico Diocesano de León, Libros de Bautismos, 299, 300, 326, 327, 328, 329, 656, 657, 659, 670 y 671. Entre 1680 y 1694 se registran, efectivamente, los niveles más reducidos de las tres variables. Tomando como base 100 los valores medios calculados para el tramo 1569.1599 - 1584 1599, en lo atinente a los bautismos-, el promedio anual de bautizados supuso, en el decenio $1680-89$, un 40,5 por 100; la producción de trigo, un índice ligeramente superior al 58 por $100, y$ las rentas de heredades, en 1685.1694 , un porcentaje del 44,4 por 100 . 


\section{GRAFICO 2}

Diezmos, rentas y bautismos en León (1570-1835)

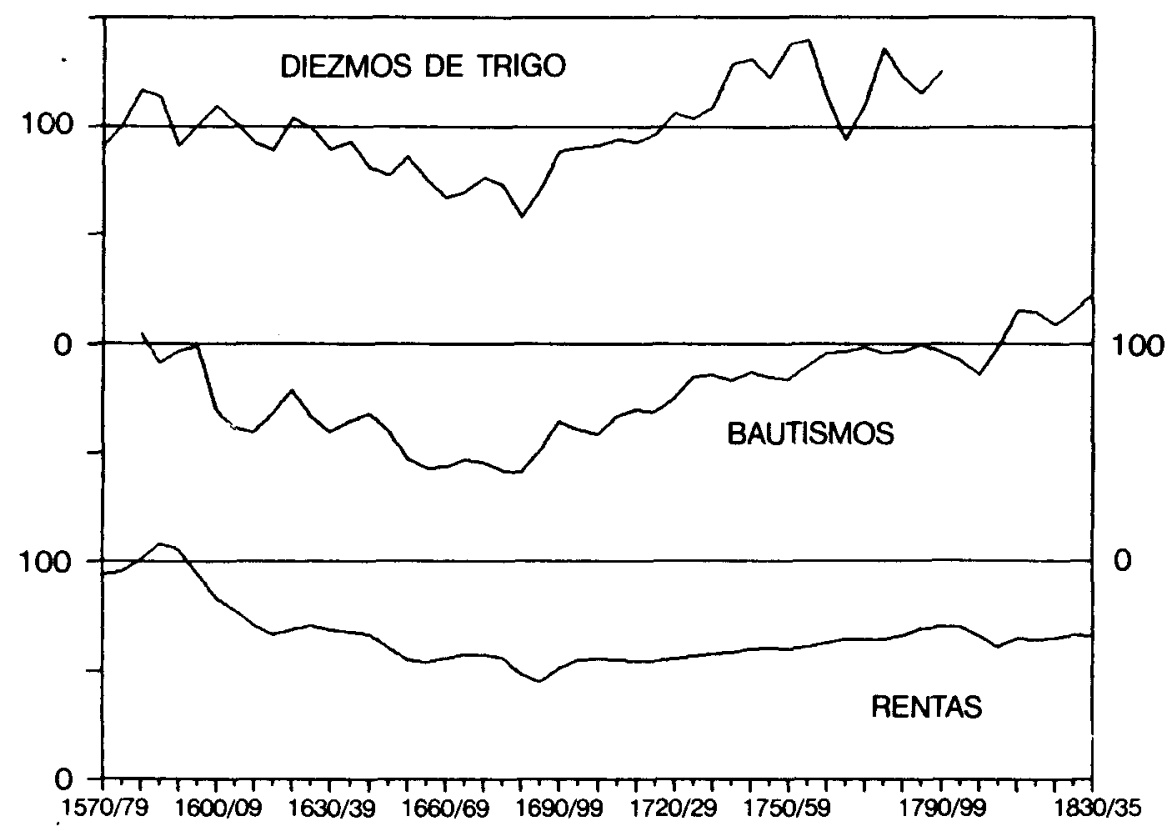

Medias anuales por decenios montados

4) 1655-1683, particularizado por una ligera recuperación de las rentas, que no trastocó el episodio negativo de 1663 , y un estancamiento posterior, definido hasta 1683 por un porcentaje que fluctuó en torno al 55,8 por 100 .

5) 1684-1689, en el que tuvo lugar una nueva contracción que arrastraría hasta su mínimo al referido índice, registrando un 39,8 por 100 en 1689 , siempre respecto a la media obtenida en $1569-1599^{28}$.

De 1689 a 1790, se operó un sustancial incremento en las rentas que por el aprovechamiento de sus haciendas recibía anualmente el Monasterio de Sandoval; dicho avance, sin embargo, no logró la envergadura necesaria

${ }^{28}$ Por estos años, exactamente entre 1684 y 1691, la tasa media de la renta estimada para las 14 heredades citadas en la nota 25 resultó igual a 0,25 fanegas de grano por fanega arrendada $-0,48 \mathrm{HI} / \mathrm{Ha}$. - lo que, utilizando de nuevo un rendimiento de $1: 4$, supondría un 12,5 por 100 del producto bruto anual. Ello da idea del desplome experimentado por las rentas del cenobio. 
para situar la cuantía de aquéllas en los niveles que habían conocido a fines del siglo xvr. Como en lo referente al período anterior, también pueden diferenciarse varios tramos en esta etapa.

1) 1690-1699, un decenio de rápido aumento que permitió la vuelta, en los años postreros del siglo, a los volúmenes de grano recogidos a finales de la década de 1670 , suponiendo éstos, en 1699 , un 55,8 por 100 del promedio atribuido al último tercio del Quinientos.

2) 1700-1720, intervalo caracterizado por el estancamiento e, incluso. por la leve disminución de las rentas, que llevó el índice aludido hasta el 52,8 por 100 en el último año citado.

3) 1721-1778, lapso de crecimiento moderado pero sostenido que, sólo con un contratiempo en 1749-1754, elevó la proporción indicada hasta el 63,3 por 100 .

4) 1779-1790, período singularizado por un avance más rápido que permitió progresar hasta su culmen al mencionado índice, cifrado en el 72,2 por 100 en $1790^{29}$.

Este, estancado en torno al 70 por 100 entre 1790 y 1805 , conoció un descenso, distante de un verdadero desplome, entre dicho año y 1808 , en razón de los débitos, atrasos y reducciones que afectaron a las rentas a raíz de la difícil coyuntura que atravesó la producción agrícola durante los primeros años del nuevo siglo. La espectacular caída que el gráfico 1 refleja para 1809 , fue fruto de esta situación, pero, sobre todo, de la imposibilidad de ingresar pagos diferidos con posterioridad al 31 de diciembre del citado año, fecha en la que fue suprimida la abadia. Tras el retorno de los monjes al claustro y la devolución de su patrimonio, en 1814, sus rentas en especie, si bien fluctuaron entre porcentajes del 60 al 67 por 100 respecto a la base considerada, no parece que sufriesen el grado de defraudación que habían empezado a acusar los diezmos y las rentas, fueros y derechos sufragados en dinero ${ }^{30}$. Después del interregno que supuso la exclaustración decretada por

${ }^{29}$ Siguiendo con el ejemplo de las 14 fincas reiteradamente citadas, su tasa de la renta, por término medio, alcanzó las 0,44 fanegas de grano por fanega arrendada $-0,85 \mathrm{Hl}$ / hectárea- entre los años 1790 y 1797 . Con un rendimiento de $1: 4$, ello equivaldría a una detracción media sobre el producto anual del 22 por 100 .

${ }^{30}$ De hecho, en lo que atañe al gráfico 2, si he optado por representar el perfil de la producción de trigo sólo hasta 1795, no ha sido por falta de datos para los años posteriores, sino por estar persuadido de que tanto los breves pontificios derogatorios de la exención de abonar diezmos por sus haciendas de que gozaban los cistercienses, publicados en 1796, como el creciente fraude verificado por los campesinos, especialmente desde 1808, propiciaron que los ingresos decimales del cenobio dejasen de traducir fielmente la marcha del producto cereal. 


\section{CUADRO 2}

Evolución de la renta otorgada por 14 beredades de Sandoval (1510-1835). Medias anuales en fanegas de todo pan

\begin{tabular}{|c|c|c|c|}
\hline Periodos & Media anual & Indice & $\begin{array}{c}\text { Tasa de crecimiento } \\
(\%)\end{array}$ \\
\hline $\begin{array}{cccc}1510-1540 & \ldots & \ldots & \ldots\end{array}$ & $1.920,7$ & 100,00 & - \\
\hline $1588-1593 \quad \ldots \quad \ldots \ldots$ & $2.572,0$ & 133,91 & $0,59(1540-1590)$ \\
\hline $\begin{array}{cccc}1684-1691 & \ldots & \ldots & \ldots\end{array}$ & 809,3 & 42,14 & $-1,17(1590-1688)$ \\
\hline $\begin{array}{cccc}1790-1797 & \ldots & \ldots & \ldots\end{array}$ & $1.665,4$ & 86,71 & $0,68(1688-1794)$ \\
\hline $\begin{array}{cccc}1826-1832 & \ldots & \ldots & \ldots\end{array}$ & $1.600,8$ & 83,34 & $-0,11(1794-1829)$ \\
\hline
\end{tabular}

Fuentes: Las señaladas en el cuadro 1 y en las notas 15,18 y 20.

los gobernantes del Trienio, las rentas se mantuvieron casi inmóviles, en torno a los niveles de 1808, hasta la extinción de la abadía en 1835 .

Este derrotero así diseñado —análogo al que, de forma resumida, se recoge en el cuadro anterior-guarda similitudes, así como ciertas diferencias, con los establecidos para las rentas de heredades en otros ámbitos de la Submeseta Norte. Eligiendo cuatro términos de comparación entre los disponibles, puede afirmarse que la evolución de la renta de la tierra en el Oriente leonés resulta plenamente afín en lo que atañe al signo de las grandes fases, presentando algunas particularidades en cuanto a su cronología. Estas la situarían entre las trayectorias que, a partir de las rentas percibidas por los cabildos catedralicios de Segovia y Zamora, cabe admitir como representativas de dichas provincias ${ }^{31}$ y la que se deriva, para tierras palentinas, de las obtenidas por el Hospital de San Antolín ${ }^{32}$, asemejándose, sobre todo, a la que puede estimarse merced a ciertas series atinentes al Monasterio de El Escorial ${ }^{33}$.

En efecto, en lo referente a Segovia, destaca la consecución del nivel mínimo, en el seno del descenso que caracterizó a la renta durante la primera mitad del Seiscientos, hacia 1650, treinta años antes de que otro tal aconteciese en el Oriente leonés, siendo éste, además, bastante menos pronunciado ${ }^{34}$; ello propició una recuperación más temprana de las mismas, favore-

3 Angel García Sanz (1977), pp. 301 y ss., y José Antonio Alvarez Vázquez (1984), p. 617 , y (1987), pp. 52 y ss.

32 Álberto Marcos Martín (1985), pp. 211 y ss.

${ }^{33}$ Gregorio Sánchez Meco (1985), pp. 61 a 71.

${ }^{34}$ En relación a los años postreros del siglo Xvi, las rentas reunidas por el cabildo segoviano hacia 1650 habían retrocedido en un 30 por 100; como hemos visto, en compara- 
ciendo que, a finales del siglo xviII, se lograsen en tierras segovianas cuantías más cercanas a las máximas del Quinientos que en nuestro territorio. En lo que hace a Zamora, el retroceso de las rentas también tocó fondo en torno a 1655, estancándose luego éstas hasta 1675 e iniciando una ligera recuperación durante los años ochenta y noventa; los mínimos registrados entre 1710 y 1726 no impidieron un paulatino avance que permitió alcanzar en 1780 niveles similares a los conocidos a fines del xvi. Por contra, en tierras de Palencia, el aumento de las rentas propio de la segunda mitad del Quinientos se mantuvo hasta 1620 , retrocediendo éstas sensiblemente durante los años treinta, deterioro que se acentuó después de 1680, dando lugar a una tardía recuperación en el transcurso del Setecientos que no posibilitó el retorno a los valores conseguidos a comienzos del siglo xvir. En cuanto a 11 «rentillas» pertenecientes al Monasterio de El Escorial, tras el máximo consignado entre 1570 y 1580 , sus importes cayeron casi ininterrumpidamente hasta el quinquenio $1690 / 95$, significando entonces apenas un 43 por 100 del promedio calculado para el lapso aludido de finales del siglo xvi; la gradual recuperación operada desde 1696 llegó a su culmen hacia 1765, suponiendo entonces un 85 por 100 respecto a la base indicada ${ }^{35}$.

\section{La determinación de las rentas en el Oriente leonés. Algunas consideraciones sobre los factores en liza}

La cuantía de la renta exigida, en un instante dado, por el usufructo de una heredad era fruto de la concurrencia de diversos elementos, los cuales pueden agruparse, a mi juicio, en tres apartados. En un extremo, los derivados de los rasgos distintivos de la hacienda en cuestión; en el otro, los de indole coyuntural, dependientes de los niveles de oferta y demanda de tierra en disposición de cederse y del concerniente a la producción de las especies en que se requerían los pagos; entre ambos, por último, un amplio elenco de factores, determinados históricamente, que cabe ordenar en torno a dos asuntos: las condiciones anexas a la renta, constituidas o no en componentes de ésta, que podían modificar su importe, y los vínculos existentes entre los cultivadores, las tierras objeto de locación y los propietarios de las mismas.

ción con la media ingresada en el último tercio del Quinientos, las rentas recaudadas por Sandoval habían disminuido en un 60 por 100 en la década de 1680 .

${ }^{35} \mathrm{El}$ arrendamiento de cuatro cotos redondos del cenobio escurialense -Marugán, Muñomer, Chavente y Jimenagorda - conoció una trayectoria aún menos lucida: respecto a la media del período $1565-1580$, sus rentas sólo equivalían a un 37 por 100 en 1660, porcentaje que únicamente alcanzaría el 41 por 100 en 1750 y el 49 por 100 en 1795; Gregorio Sánchez Meco (1985), pp. 61 y 62. 
1) Como es obvio, la natural heterogeneidad de las fincas propiciaba un considerable grado de variabilidad de las rentas otorgadas, las cuales, en términos unitarios y en un momento dado, resultaban muy dispares ${ }^{36}$. En lo tocante al tamaño de los predios, parece confirmarse en nuestro territorio lo apuntado por Alberto Marcos para tierras palentinas, a saber, que la renta por unidad de superficie - y, por tanto, la deducción sobre lo cosechadotendía a decrecer conforme aumentaba la dimensión de las haciendas ${ }^{37}$.

$\mathrm{Si}$ el cuadro 3 ilustra sobre dicho fenómeno, el cuadro 4 , que incluye algunos ejemṕlos de haciendas de similar extensión y desigual calidad, sugiere que, al respecto, la dispar fertilidad de los suelos marcaba una frontera quizá más decisiva.

\section{CUADRO 3}

Rentas por unidad de superficie arrendada obtenidas por Sandoval, según el tamaño de las fincas, bacia 1752

\begin{tabular}{|c|c|c|c|}
\hline Dimensión en Has. & $\begin{array}{l}\text { Numero de } \\
\text { beredades }\end{array}$ & $\begin{array}{c}\text { Tasa media } \\
\text { fanegas/fanega }\end{array}$ & $\begin{array}{l}\text { Tasa media } \\
\mathrm{H} / / \mathrm{Ha} .\end{array}$ \\
\hline 0,4 a $4,9 \ldots \ldots \ldots \ldots \ldots$ & 14 & 0,405 & 0,780 \\
\hline 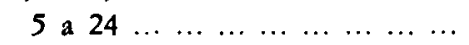 & 18 & 0,395 & 0,762 \\
\hline 25 a $50 \ldots \ldots \ldots \ldots \ldots$ & 6 & 0,359 & 0,693 \\
\hline \multirow{2}{*}{ Más de $\begin{array}{lllllllll}50 & \ldots & \ldots & \ldots & \ldots & \ldots & \ldots & \ldots\end{array}$} & 10 & 0,304 & 0,586 \\
\hline & 48 & 0,374 & 0,722 \\
\hline
\end{tabular}

FUENTES: Las citadas en la nota 36.

${ }^{36}$ Para la época del Catastro de Ensenada, sobre una muestra de 48 heredades pertenecientes a Sandoval, se obtiene una tasa media de la renta de $0,72 \mathrm{Hl} / \mathrm{Ha}$, cuyo coeficiente de variación anejo - 59,72- trasluce una dispersión que se situaba entre extremos tales como 2,41 y $0,12 \mathrm{Hl} / \mathrm{Ha}$. Archivo Histórico Provincial de León, Respuestas Particulares del Catastro, cajas 7901, 8.028, 8.068, 8.135, 8.197, 8.213, 8.214, 8.221, 8.318, 8.338, 8.550, $8.588,8.604,8.660,8.662,8.689,8.712,8.867,8.879,8.903,8.917,8.918,8.923,8.969$, $8.992,9.045,9.055,9.057,9.063,9.078,9.080,9.082,9.087$ y 9.089; Archivo General de Simancas, Dirección General de Rentas, 1." Remesa, Respuestas Generales, libs. 363, 365,650 y 653, y Libros de los Mayores Hacendados, 414, 417 y 422 ; AHN, Clero, Apeos, libs. 5152,5155 y 5156, y legs. $2745,2747,2748,2752,2755$ y 2759 , amén de los testimonios sobre escrituras de cesión citados en la nota 15.

${ }^{37}$ Alberto Marcos Martín (1985), pp. 203 y ss. 


\section{CUADRO 4}

La renta y la bondad de los suelos, hacia 1752

\begin{tabular}{|c|c|c|c|c|c|}
\hline Fincas monacales en & $\begin{array}{l}\text { Extensión } \\
\text { en Has. }\end{array}$ & $\begin{array}{c}1.4 \text { calidad } \\
(\%)\end{array}$ & $\begin{array}{l}2 .^{n} \text { calidad } \\
(\%)\end{array}$ & $\begin{array}{l}\text { 3." calidad } \\
(\%)\end{array}$ & $\begin{array}{c}\text { Tasa media } \\
\mathrm{Hl} / \mathrm{Ha}\end{array}$ \\
\hline Roderos $\ldots \ldots \ldots \ldots$ & 54,4 & 52 & 46 & 2 & 0,92 \\
\hline $\begin{array}{lllll}\text { Villalquite } & \ldots & \ldots & \ldots\end{array}$ & 50,5 & 0 & 21 & 79 & 0,17 \\
\hline Grajal/Oteros $\ldots \ldots$ & 3,5 & 5 & 95 & 0 & 0,93 \\
\hline Valdesaz/Oteros .... & 3,6 & 16 & 84 & 0 & 1,01 \\
\hline Sahelices/Payuelo ... & 1,8 & 0 & 41 & 59 & 0,21 \\
\hline S. Justo/Oteros . ... & 1,0 & 0 & 92 & 8 & 0,36 \\
\hline
\end{tabular}

FuENTES: Las citadas en la nota 36.

La renta, pues, particularmente sensible a la calidad del terreno, acusaba las diferencias existentes, ora si éstas eran notables, como entre las fincas de los bernardos sitas en Roderos y en Villalquite, ora si eran ínfimas, como entre las ubicadas en Grajal y Valdesaz de los Oteros. En ausencia de modificaciones, ya fueren debidas a la introducción de mejoras como un abonado más eficaz, ya a la intervención de otros factores, estos contrastes tendían a mantenerse en el transcurso del tiempo ${ }^{38}$.

Como es sabido, también la situación de los predios ejercía influencia sobre las rentas, siendo probable, por ejemplo, que éstas fuesen más altas en el caso de aquéllos que presentaban especiales facilidades de acceso para sus locatarios, por hallarse próximos a sus viviendas, evitando largos despla-

${ }^{38}$ Así aconteció con la heredad monacal de Gusendos de los Oteros, la cual, peor dotada de buenos suelos que su homóloga de Campo de Villavidel, otorgó durante dos siglos una renta unitaria inferior.

\begin{tabular}{|c|c|c|c|c|c|}
\hline $\begin{array}{l}\text { Haciendas } \\
\text { sitas en }\end{array}$ & $\begin{array}{l}\text { Extensión } \\
\text { en tanegas }\end{array}$ & $\begin{array}{l}\text { Promedio } \\
1510-40 \text { * }\end{array}$ & $\begin{array}{l}\text { Promedio } \\
1588-93 *\end{array}$ & $\begin{array}{l}\text { Promedio } \\
1684-91\end{array}$ & $\begin{array}{l}\text { Promedio } \\
1720-29\end{array}$ \\
\hline $\begin{array}{llll}\text { Gusendos } & \ldots & \ldots & \ldots\end{array}$ & 115,9 & 0,56 & 0,72 & 0,23 & 0,21 \\
\hline Campo $\ldots \ldots \ldots$ & 115,5 & 0,69 & 1,21 & 0,41 & 0,49 \\
\hline
\end{tabular}

* Fanegas de todo pan por fanega arrendada.

Fuentes: Las citadas en las notas $15,18,20$ y 36. 
zamientos a las bestias de labranza. No obstante, no dispongo de datos que evidencien este particular ${ }^{39}$.

2) Es evidente que la renta, como precio concertado por el aprovechamiento de la tierra, guardaba una estrecha relación con el nivel en que se situase la continua interacción entre oferta de terreno en usufructo y demanda del mismo. Sin embargo, en la Castilla del Antiguo Régimen, el libre juego de ambas variables se hallaba mediatizado por no pocos factores. En lo que atañe a la oferta, ésta dependía, en cada localidad, de la proporción existente entre el espacio de labor propio de los cultivadores directos - y sus posibilidades de expansión sobre los comunales- y el perteneciente a personas que no atendían directamente a su explotación ${ }^{40}$. Asimismo, las cuantías que alcanzasen las rentas estaban ligadas al número de propietarios que tenían parte en la segunda porción citada y al modo según el cual se distribuyese ésta entre los mismos, fomentando una mayor o menor competencia a la hora de negociar las cesiones. En lo concerniente al monasterio bernardo se aprecia un contraste, en todo momento $-\mathrm{y}$, en algunos, sustancial-, entre las rentas ingresadas por su hacienda de Villaverde de Sandoval, lugar en el que todo el término pertenecía a los monjes, y aquellas otras provenientes de núcleos en los que el cenobio era, únicamente, uno más de los propietarios locadores ${ }^{41}$.

Por el lado de la demanda, a la relación básica entre efectivos demográficos y subsistencias obtenidas en labrantíos propios y, en su caso, en áreas de aprovechamiento colectivo, se añadían, aparte de otros elementos que tendremos ocasión de considerar, las posibilidades de sostenimiento derivadas

${ }^{39}$ Tampoco cuento con testimonios que aducir ante una cuestión suscitada por Alberto Marcos, v. gr., que las rentas solían ser menos elevadas cuando los propietarios eran institutos eclesiásticos que cuando se trataba de personas particulares, si bien, en mi opinión, ello dependería del tipo de entidad de que se tratase y del grado de control que lograse ejercer sobre su patrimonio. Parece razonable que una mayor dispersión del mismo, como indica el citado autor, tendiese a favorecer a los llevadores de las parcelas más alejadas; sin embargo, no pocas haciendas distantes del claustro de Sandoval proporcionaban rentas superiores a las otorgadas por otras más cercanas. En cualquier caso, estoy de acuerdo con el corolario que, de dichas observaciones, extrae Alberto Marcos, a saber, que muchas instituciones religiosas - -especialmente las más antiguas-, por estos o por otros motivos, fueron más proclives, durante los siglos xvir y xvir, a arbitrar políticas de racionalización, concentración y control de sus acervos rústicos que a sustentar un incesante aumento de los mismos mediante la adquisición de nuevas propiedades. A. Marcos Martín (1985), p. 207.

${ }^{40}$ En buena medida, como indica Alberto Marcos (1985), p. 206, del grado de amortización de la propiedad.

"La renta unitaria otorgada por la heredad de Villaverde, en comparación con la media calculada para las 14 fincas citadas en la nota 25 , registró valores superiores en un 42 por 100 a ésta en pcríodos de rentas altas, como 1588-1591 y 1790-1797, situándose por encima, incluso en un 125 por 100, en épocas de rentas bajas, como 1684-1691. 
de otras actividades, en bastantes aldeas leonesas, del hilado y del tisaje domésticos del lino $y$, en todas, de la ganadería ${ }^{42}$.

Amén de ello, en lo que hace a una magnitud tan importante como la producción de granos, corroborando una vez más lo observado para Palencia por Alberto Marcos, más que la tendencia secular de ésta, parecen ser sus fluctuaciones a corto plazo las que más directamente influían sobre la trayectoria de las rentas en nuestro ámbito. El sentido de dicha influencia, claro es, resultaba distinto según el marco en que se operasen las citadas oscilaciones; así, en un período de relajación de la presión de la demanda sobre el producto cereal, como la mayor parte del siglo xvir, las rentas evolucionaron paralelamente a éste ${ }^{43}$. En cambio, en lapsos en los cuales la oferta de granos se mostró incapaz de satisfacer la demanda de los mismos, las rentas tendieron a seguir más de cerca el movimiento de los precios que el de la producción ${ }^{44}$.

Las variables citadas hasta aquí suelen ser las más comúnmente invocadas a la hora de analizar la evolución de la renta de la tierra en el transcurso de la Edad Moderna; junto a ellas, empero, actuaban otros elementos de indo'e menos genérica, acerca de los cuales conviene llamar la atención.

3) En la práctica, se comprueba que sobre el nivel alcanzado en cada momento por las rentas de heredades, ejercían su ascendiente, con mayor o menor vigor según los casos, diversos factores concomitantes con la citada magnitud, cuyas variaciones podían alterar su cuantía. Me limitaré, siempre con la apoyatura de los fondos de Sandoval, a señalar tres.

${ }^{42}$ El gráfico 2 ofrece una buena muestra de los paralelismos existentes entre la evolu. ción de la población en nuestra zona y la de las rentas de heredades de pan llevar. Por otra parte, hay razones para sospechar que, en la misma, uno de los factores que coadyu. varon a la permanencia en niveles muy bajos de las mencionadas rentas durante buena parte del siglo XVII - amén del probable exceso de oferta de tierra, derivado del retroceso poblacional - fue el impulso recibido por la ganadería estante y los ingresos complementarios que ésta propició para no pocas economías campesinas.

${ }^{43}$ Los ejemplos son muy numerosos, algunos obvios, como los referidos al decenio de 1680 , por lo que basta con mencionar uno, destacable precisamente por acontecer en un tramo de notabilísimo deterioro de las rentas. En efecto, en el seno de una coyuntura adversa para la producción de áridos como la definida por el tránsito del siglo XVI al XVII, una racha de cosechas aceptables habida en el Oriente leonés entre 1601 y 1606 -auténtico lapso de calma entre las intensas oscilaciones a la baja de 1595-1598 y 1608- implicó la detención momentánea del descenso de las rentas, dando lugar al escalón que puede observarse en el gráfico 1.

* Ciertamente, a fines del siglo XVI, mientras la producción de áridos comenzó a disminuir a mediados de la década de 1580 , las rentas crecieron - y se situaron' en sus niveles máximos- hasta 1596; análogamente, mientras que la recuperación productiva ex. perimentada en la zona durante el siglo xviII culminó en torno a 1755 , las rentas siguieron creciendo hasta 1790. 
a) La duración de los plazos de cesión de las baciendas.--En lo tocante a los arrendamientos suscritos por los cistercienses, se aprecia como habitual que, cuando tras un período de incremento de la renta, se operaba una minoración de la misma, ésta trajese aparejado un acortamiento del lapso de cesión ${ }^{45}$. Si el recorte sufrido por la renta sólo era transitorio, el interés de los potenciales llevadores por retornar a los plazos de cesión primitivos podía contribuir a que aceptasen ulteriores subidas de aquélla. Ahora bien, si el descenso no resultaba meramente coyuntural, los menores plazos de cesión tendían a sucederse, constituyendo uno más de los motivos que desincentivaban a los locatarios a elevar las rentas y pudiendo coadyuvar, incluso, a posteriores deterioros de la misma. Así ocurrió durante el siglo xvir, centuria que, en comparación con la anterior y la posterior, registró una reducción generalizada de los plazos de arriendo de las fincas monacales, como se aprecia a continuación.

\section{CUADRO 5}

Duraciones media y modal de los arrendamientos acordados por Sandoval (1510-1835). En años

\begin{tabular}{|c|c|c|c|c|c|}
\hline Periodos & $\begin{array}{c}\text { Número de } \\
\text { escrituras }\end{array}$ & $\begin{array}{l}\text { Plazo } \\
\text { medio }\end{array}$ & $\begin{array}{l}\text { Coeficienle } \\
\text { de variación }\end{array}$ & $\begin{array}{l}\text { Plazo } \\
\text { modal }\end{array}$ & $\begin{array}{c}\text { Plazo modal/ } \\
\text { total con- } \\
\text { tratos }(\%)\end{array}$ \\
\hline $\begin{array}{llll}1510-1599 & \ldots & \ldots \\
1600-1699 & . & \ldots & \ldots \\
1700-1799 & . & \ldots & \ldots \\
1800-1835 & . & \ldots & \ldots\end{array}$ & $\begin{array}{r}132 \\
243 \\
245 \\
78\end{array}$ & $\begin{array}{l}8,43 \\
6,65 \\
7,84 \\
7,47\end{array}$ & $\begin{array}{l}24,0 \\
30,7 \\
19,4 \\
22,9\end{array}$ & $\begin{array}{l}9 \\
6 \\
8 \\
8\end{array}$ & $\begin{array}{l}81,0 \\
30,6 \\
50,6 \\
77,0\end{array}$ \\
\hline Total ... ... & 698 & 7,50 & 26,7 & 8 y 9 & 70,9 \\
\hline
\end{tabular}

Fuentes: Las citadas en las notas 15,17 y 20.

${ }^{45}$ Asi, durante la primera década del siglo xvII, en el inicio del sustancial retroceso de las rentas que ya conocemos, de ocho heredades monásticas que han conservado todas las escrituras formalizadas por entonces, lo dicho aconteció en seis, las cuales pasaron de estar cedidas por nueve años a ser entregadas por un máximo de siete y un mínimo de tres. Igualmente, cuando en 1775, en una época de avance de las rentas, los monjes transigieron con una rebaja de la otorgada por la heredad de Villaverde, «por los daños que el Rio de Villarente ha hecho en el terminom, limitaron de nueve a seis años el plazo de vigencia. AHIN, Clero, Escrituras de arrendamiento, lib. 5196 y legs. 2755 y 2757. 
Obviamente, la disminución de los plazos de cesión debe entenderse como un primer intento llevado a cabo por los regulares para menguar el impacto del retroceso de las rentas en sus ingresos. Si dicho fenómeno se dejó sentir de modo especial durante el siglo xvir, ello acaeció porque la caída de las rentas habida en su transcurso no fue lineal, sino escalonada - como observamos en el gráfico 1-, posibilitando que aquél se reprodujese. Es indudable que, llegadas las rentas a cierto punto, el citado mecanismo se tornaba contraproducente, imponiéndose la estrategia contraria con el propósito de atenuar el deterioro de las mismas. Llevada a su extremo, esta última supuso, en ciertos casos, el cambio en la modalidad de cesión de la tierra, pasándose del arrendamiento al foro vitalicio; singularmente, en momentos en que nada permitía presagiarlo, dicha transformación implicó un incremento sustancial de las rentas de las haciendas afectadas ${ }^{46}$.

b) Otras obligaciones anexas a la renta.-Hemos dado por hecho, hasta aquí, que las rentas de los predios del cenobio estaban integradas, exclusivamente, por cuantías variables de medidas de grano; ello, empero, no es exacto, en especial, para las cesiones formalizadas en el transcurso del Quinientos. En efecto, durante dicho siglo fue muy frecuente que, junto a los cereales, se exigiese a los renteros la entrega anual de cierto número de gallinas, carneros, carros de paja, libras de cera e, incluso, monedas, abonos cuyo origen se remontaba a los cambios habidos en la composición de la renta feudal del monasterio desde el medievo ${ }^{47}$. Existen indicios suficientes en la docu-

t6 Ciertamente, de un lado, el aforamiento de heredades se hizo mucho más frecuente durante la segunda mitad del Seiscientos: frente a los tres contratos de este tipo acordados entre 1601 y 1650 , fueron 16 los estipulados entre 1651 y 1700 . De otro, las seis fincas del cenobio que han conservado las escrituras de arriendo inmediatamente anteriores - redactadas entre 1659 y 1691 - a su aforamiento -establecido entre 1666 y 1698 - experimentaron un incremento medio de sus rentas del orden del 73 por 100, pasando de proporcionar, en conjunto, 136,7 fanegas anuales a otorgar 236,7 .

${ }^{47}$ Entre los muchos ejemplos disponibles, cabe mencionar uno:

\begin{tabular}{lrl}
\hline Arriendos & & \multicolumn{2}{c}{ Heredad de Gusendos de los Oteros } \\
\cline { 1 - 1 } 1512 & & 12 gallinas y 3 libras de cera. \\
1524 & 8 & gallinas, 4 libras de cera, 2 carneros y un carro de paja. \\
1536 & & 8 gallinas. \\
1557 & & 8 gallinas y una libra de cera. \\
1566 & & 8 gallinas y una libra de cera. \\
1575 & 9 gallinas, una libra de cera y 1,7 fanegas de trigo. \\
\hline
\end{tabular}

Fuente: AHN, Clero, Escrituras de arriendo, leg. 2750.

Puede apreciarse que entrañaban deducciones sobre lo obtenido de actividades que bien podían desarrollarse fuera de los predios arrendados a los monjes. En cuanto a su importancia, veremos en lo tocante al coto monástico que ésta no era tan baladí como pudiese parecer. 
mentación claustral para presumir que estos pagos hacian alusión a formas pretéritas de renta, quizá a la conmutación de prestaciones personales y a derechos sufragados en reconocimiento de antiguas potestades jurisdiccionales, las cuales habían quedado adheridas a la renta en especie cereal desde que ésta, en el curso del siglo xv, había pasado a conformar el grueso de la renta feudal de la abadia ${ }^{48}$.

Importa resaltar la caída en desuso de su imposición, salvo en lo referente a algunas haciendas, durante el siglo xvir y su paulatina desaparición de las escrituras de cesión, tal vez en un esfuerzo por preservar lo fundamental; dicho acontecimiento dota de mayor dimensión a la, de por sí considerable, disminución de las anualidades sufragadas por las fincas de la abadia, acaecida en dicha centuria. Su supervivencia en el siglo xvirr, restringida prácticamente al coto monástico, ilustra acerca del empleo que, de antiguas formas de aprovechamiento de la fuerza de trabajo campesina, podían verificar ciertos privilegiados incluso en el llamado Siglo de las Luces ${ }^{49}$.

c) La imputación del transporte de las especies devengadas.-Por último, el establecimiento de cuál debía ser la parte contratante que, en cada cesión, se hiciese cargo del acarreo de los granos hasta el monasterio, no era una cuestión trivial en el seno de un dominio caracterizado, como tantos otros, por su dispersión. Los cistercienses de Sandoval habían logrado imponer la citada obligación a la mayoría de los llevadores de sus haciendas, al igual que otros grandes propietarios castellano-leoneses, en el curso del Quinientos ${ }^{50}$. Sin embargo, aunque no en todos los casos, este aspecto pasó a ser materia negociable entre la comunidad y los renteros durante el siglo xvII; la imputación aludida varió entonces de la una a los otros al compás del movimiento de las rentas y de los cambios en los plazos de cesión, influyendo, a su vez, sobre ambos elementos. Así, en ocasiones, los bernardos pretendieron paliar el retroceso de la renta exigiendo de sus pagadores el acarreo de la misma; en otras, fue preciso que los regulares cediesen también en este

${ }^{48}$ En dicho carácter abunda el que su alcance estuviese más en función del número de llevadores de las fincas que de la evolución del volumen de áridos satisfecho.

49 Según el arrendamiento estipulado en 1756 - AHN, Clero, leg. 2759-, cada usufructuario de uno de los trece quiñones de tierras de los que constaba la heredad de Villaverde de Sandoval debía contribuir anualmente con 44 fanegas de pan mediado trigo y cebada, dos carros de paja buena, un carro de leña del monte del Membrillar - propio del cenobio- "cuando se les mandase», una serna «de trabajo personal para meter la yerba» en los almiares de la abadía y 16 leguas de «sernas de caminos a donde les mande el $\mathrm{M}^{\circ}$. con su carro, bueies y persona a traer trigo o vino o otra cossam. Amén de ello, debían entregar el diezmo completo de trigo, cebada y centeno, cuatro gallinas vivas por el diezmo de lino y cáñamo y 12 celemines de mediado trigo y cebada en concepto de primicia.

so Lo cual, junto a los servicios de transporte que obtenían gratuitamente de los vecinos del coto monacal, les permitió minimizar la significación de dicho renglón en sus gastos totales. 
terreno para lograr arrendar los predios; hubo casos en los que el cenobio consiguió imponer casi todas sus condiciones y otros, en fin, en que sólo merced a hacerse cargo del transporte, obtuvo un alza de la renta ${ }^{51}$.

4) Para finalizar, corviene parar mientes en un conjunto de factores cuya influencia sobre el nivel alcanzado por las rentas de Sandoval en cada etapa de la Edad Moderna no puede juzgarse despreciable. Estos, relativos a los vínculos existentes entre las poblaciones en cuyos términos radicaban haciendas del cenobio, la explotación de éstas y el propio monasterio, hundían sus raíces en los siglos xII y xIII, cuando la conformación del patrimonio claustral no sólo supuso la incorporación de un notable volumen de tierra, sino también la de prerrogativas económicas y jurisdiccionales sobre los habitantes de los núcleos aledaños. La lozanía de dichos nexos en el Antiguo Régimen, empero, sólo resulta comprensible si se considera un fundamento clave del paisaje rural del Oriente leonés, a saber, su peculiar poblamiento concretado en una tupida red de pequeñas aldeas bastante próximas entre sí y dotadas de reducidos términos, el cual sobrevivió, tanto a los durísimos avatares de la época bajomedieval, como a los propios de los siglos modernos ${ }^{52}$.

Esta singularidad, presente también en otras áreas de la Submeseta Norte, propició que, en no pocos lugares, las posesiones monásticas implicasen, por

$"$ Proporcionan buenos ejemplos de los sucesos mencionados, correlativamente, la finca de Fontanilla, de cuyo arriendo, pactado por una renta menor que la usual en años anteriores en 1666, lograron los monjes el magro consuelo de que los renteros trajesen aqué. Ila a la abadía. La heredad de Gusendos, que, tras el fallecimiento de los foreros que la llevaban desde 1669 , estuvo vacante entre 1686 y 1689 , cediéndose de nuevo en 1690 a costa no sólo de volver a aforarla y de reducir no poco la renta exigida - de 32 a $21 \mathrm{fa}$ negas anuales-, sino también gracias a que la comunidad transigió con ir a buscar ésta al dicho lugar. El coto de Villamor, cuyo aforamiento en 1681 permitió a los monacales, aparte de elevar sustancialmente su renta - de 40 a 100 fanegas anuales-, exigir de sus llevadores que la acarreasen cada año hasta el claustro. Por último, la hacienda sita en Fresno de la Vega, la cual, tras andar arrendada tan sólo en 16 fanegas entre 1684 y 1696, consiguieron los bernardos que la tomasen varios vecinos por 35 , en 1697 , a cambio de obligarse ellos a correr con su transporte, cosa que no ocurría desde 1575. Las fuentes de estos testimonios son las citadas en la nota 15.

32 El panorama que, a mediados del siglo Xvirr, mostraban las Respuestas Generales del Catastro de Ensenada se ajusta plenamente a dicha caracterización; a partir de una muestra de 54 localidades, la extensión media de los términos se situaba en torno a 770 Has., obteniéndose promedios de 32 vecinos y 40 casas por lugar-AGS, DGR, $1{ }^{2}$ Rem. RG, libs. 329, 330, 331, 334, 336, 353, 355, 356, 357, 358, 359, 361, 362, 363, $364,365,650,653$ y 657 - En mi opinión, esta circunstancia, junto a la preponderancia desde antiguo de la propiedad privilegiada y la correlativa abundancia de campesinos usufructuarios de predios ajenos, en el marco de pequeñas explotaciones, fomentó que fuese menor el grado de diferenciación social en el seno de las aldeas leonesas que en el de las villas de mayor fuste del centro de la cuenca duriense. Ello permitió, a su vez, el man. tenimiento de una inusual fortaleza de las comunidades aldeanas hasta fines del Antiguo Régimen y la sobrevivencia de ciertos rasgos arcaicos en las relaciones propietarios-cultivares, algunos de los cuales hemos podido apreciar. 
su extensión así como por su calidad, una porción sustancial de los labrantíos disponibles, cuyo aprovechamiento resultaba indispensable para cierto número de vecinos, cuando no para todos ${ }^{53}$. La confluencia entre las necesidades de las familias campesinas, de un lado, y el afán de los cistercienses por obtener utilidades de sus haciendas, de otro, se articuló en torno a diversos modos de explotación de su acervo rústico que cambiaron con el paso del tiempo. Hacia mediados del siglo $\mathrm{xv}$, la organización nacida a raíz del declive demográfico que venía enseñoreando la región desde fines del siglo XIII, se revelaba particularmente obsoleta. El deterioro de los que habían dado en ser sus puntuales básicos, las rentas en dinero y las cesiones a muy largo plazo del dominio útil de los predios, alcanzaba cotas insostenibles. Si las primeras se hallaban sometidas a un acusado proceso de erosión por mor de las reiteradas devaluaciones del maravedí castellano, adoptadas por el poder regio. las segundas, tras la despoblación de numerosos enclaves ${ }^{54}$ y su renovación más o menos explícita durante varias generaciones, habían dado pie a una notable confusión acerca de quiénes eran las personas que debían sufragar los pagos, atizada ahora por los inicios de la recuperación poblacional.

La urgencia de una profunda reordenación de las relaciones así instituidas entre la abadía y los cultivadores de sus haciendas, se hizo pronto evidente a los ojos de los monjes. Esta se acometió, en efecto, entre 1480 y 1510 , sin que faltasen conflictos y fricciones, decantándose en la práctica hacia una suerte de compromiso, cuyos extremos principales pueden enunciarse como sigue. Los bernardos agruparon las fincas que poseían en el término de cada lugar bajo una sola escritura de cesión y consiguieron que ésta, en la mayoría de los casos, se concretase en un arrendamiento renovable, a lo sumo, cada nueve años, y lograron que las rentas devengadas se abonasen en especie. Los labriegos, por su parte, mediante la concertación de arrendamientos mancomunados, pasaron a participar en mayor número en el aprovechamiento de las tierras y obtuvieron del cenobio la aquiescencia tácita de que el usufructo de la heredad monacal ubicada en cada término, mientras se pagasen puntualmente las rentas, lo gozarían los vecinos del mismo y sus herederos, alcanzando, a despecho de la naturaleza de las nuevas cesiones, una razonable seguridad en el acceso al uso de las haciendas.

${ }^{5}$ Ello, claro está, no debió ser privativo del dominio de Sandoval, pudiéndose inferir otro tanto en lo atinente a otros extensos patrimonios monacales leoneses de origen medieval, como los de abadías tan notorias como Eslonza, Gradefes, Carrizo, Nogales y, desde luego, Sahagún. Quizá la trayectoria aquí esbozada sea representativa de la que éstos conocieron, si bien, hoy por hoy, no dispongo de evidencias suficientes para asegurarlo.

${ }^{54}$ He podido calcular que de los lugares habitados en el Oriente leonés hacia 1250 , en torno al 28 por 100 había desaparecido en 1591, fecha de confección del «censo de los millones». Las fuentes de dicha estimación, así como las demás cuestiones mencionadas en estos párrafos, son tratadas in extenso en mi tesis doctoral, citada en la nota 14 . 
Este entendimiento resultaría notablemente longevo, sin que las dificultades que conoció la agricultura leonesa a fines del siglo xvi y durante casi todo el xvir, ni las novedades introducidas en la legislación sobre arriendos en el último cuarto del xviı, impidiesen que constituyese la base de la explotación del patrimonio cenobítico hasta 1835. Al respecto, la abundancia de testimonios que confirman lo dicho obliga a seleccionar sólo algunos. Así, de los 362 contratos de arrendamiento estipulados, entre principios del Quinientos y la tercera década del Ochocientos, para 13 de las heredades más importantes de Sandoval, 315 -el 87 por 100 - se acordaron con mancomunidades de campesinos ${ }^{55}$, y únicamente 47 -l 13 por $100-$, con individuos en solitario ${ }^{56}$. Entre idénticas cotas temporales, se observa que 11 de las 13 haciendas consideradas se entregaron, siempre y en todo momento, a los vecinos de las aldeas homónimas en cuyos territorios radicaban ${ }^{57}$. Sólo en lo referente a las fincas de Palacino y Villamor, cotos redondos sitos en términos que se habían despoblado durante los siglos bajomedievales, se aprecia la relajación de los citados nexos, disputándose su arriendo los habitantes de varias localidades limítrofes ${ }^{58}$.

5s Según éstos, los labradores mancomunados tomaban las tierras a «todo riesgo y ventura», renunciando explícitamente a las normas que pudiesen ampararles, comprometiéndose a abonar «en el todo» las anualidades establecidas, sin poder aducir «caso fortuito del çielo e de la tierra, piedra, niebla, helada, langosta, fuego, rrobo, seca o delubio». Las rentas se prorrateaban entre los consortes a tenor de la porción de la finca que hubiese obtenido cada uno, respondiendo en común de los pagos, incluso si algún quiñón quedaba libre por muerte o emigración de su llevador. La distribución de las suertes la verificaba el abad sólo en lo concerniente al coto monástico y a la heredad de Fuentes de Carbajal; en los demás casos, el reparto y adjudicación de quiñones corría a cargo de las mancomunidades de arrendatarios. Las fuentes de todo ello son las citadas en la nota 15.

${ }^{56}$ De estos últimos, 36 -el 77 por 100 - se pactaron en el transcurso del Seiscientos, cuando cl retroceso demográfico mermó las mancomunidades, dificultando, primero, que los consortes sobrevivientes afrontasen los débitos de los desaparecidos, impidiendo, desfués, que los antedichos pudiesen cultivar la misma superficie que antes. Como mal menor, se acudió entonces, en algunas haciendas, a otorgamientos individuales de porciones, lo cual, empero, los monjes no aplicaron con asiduidad.

57 Así, la transformación operada a fines del siglo xv en los modos de aprovechamiento del patrimonio de Sandoval no vino a romper vinculaciones antiguas, sino más bien a remodelarlas, cuando no a crear otras nuevas. Existen numerosos ejemplos de linajes campesinos que, al igual que mediante foros perpetuos en los siglos medievales, se mantuvieron unidos al usufructo de los predios monásticos durante los siglos modernos; el mejor documentado es el caso de la familia Melón, afincada en Jabares de los Oteros. En efecto, desde Santos Melón, miembro de la maricomunidad que tomó a su cargo el cultivo de la heredad de Jabares en 1547, hasta Dionisio Melón, partícipe de la que hizo lo propio en 1807, se sucedieron: Bartolomé Melón en los arriendos de 1565 y 1574; Marcos y Lorenzo Melón en los de 1657 y 1666 -adviértase que existe una laguna en las escrituras conservadas para la primera mitad del siglo xvII-; Lorenzo Melón, solo, en los de 1670 , 1676 y 1681; Joseph Melón en el de 1698; Muxelo Melón en el de 1714; Alexo y Manuel Melón en los de 1733, 1741, 1747, 1751 y 1754; Juan Melón en el de 1762; Juan y Manuel Melón en los de 1768 y 1775, y Manuel y Alejo Melón en los de 1783 y 1791 . AHN, Clero, Escrituras de arrendamiento, legs. 2755 y 2757, y Memoriales cobradores de granos, libs. 5151 y 5158, y legs. 2751, 2752, 2754 y 2759. 
Una adaptación tan notable del aprovechamiento del acervo claustral al marco organizativo de las comunidades aldeanas $y$, a su través, de la pequeña explotación campesina, tuvo por fuerza que influir en el nivel de las rentas. Ciertamente, en estas condiciones, la posible competencia entre diversas localidades por alzarse con los arriendos era mínima, mientras que la que podía establecerse entre los vecinos de un mismo lugar, sólo se dejaba sentir cuando los predios en cuestión eran lo suficientemente pequeños como para acceder a su uso de forma individual o en asociaciones de dos o tres personas, diluyéndose en el seno de la mancomunidad en cuanto aquéllos contaban con cierta entidad ${ }^{59}$. Se comprende así que el procedimiento seguido para fijar las rentas no pasase, salvo excepciones, por «sacar a pregón» las heredades vacantes y verificar licitaciones, sino por la apertura de negociaciones directas entre los llevadores habituales y la comunidad, en el curso de las cuales, como vimos, amén de la cuantía de la renta, se consideraban el plazo de cesión, la existencia de otros pagos anexos y la asignación del transporte de aquélla ${ }^{\text {so. }}$.

Este reducido grado de competencia por los arriendos actuó sobre el nivel alcanzado en cada etapa por la mayoría de las rentas del cenobio, tendiendo a suavizar su magnitud, tanto en períodos de alza como en lapsos de descenso generalizado; ello, que se comprueba claramente en el cuadro siguiente, no parece, empero, que revistiese una importancia sustancial.

ss Incluso, en lo que atañe a Palacino, su usufructo, tras dirimirse entre los pueblos de Grajal y Fuentes de los Oteros en el siglo xvi, permaneció en manos de los vecinos de Valdesaz de los Oteros entre 1615 y 1835 . Sólo el coto redondo de Villamor mantuvo su disfrute desligado de los habitantes de un único lugar, accediendo al mismo, según las rentas que estuviesen dispuestos a abonar, los de Matanza, Villabraz, Zalamillas y Castil falé. Algo similar acontecía con tres heredades - Mansillexa, Santovenia y Malateriaque, aunque incluidas en el coto monacal, se hallaban equidistantes de los núcleos de Nogales, Mansilla Mayor y su arrabal de Santovenia, Villaverde y Mansilla de las Mulas, en cuyo arriendo, en uno u otro momento, participaron vecinos de todos los lugares citados.

57 Lo cual contribuye a explicar que, como comprobamos, la tasa de la renta, en promedio, resultase más elevada en lo atinente a las pequeñas fincas que en el caso de las grandes haciendas.

" En efecto, las escasísimas ocasiones en que las palabras «subasta» y «pujas» aparecen en los documentos de rentas de Sandoval remiten en su mayoría a las haciendas citadas en la nota 58. Dichas alusiones se hallan en los raros asientos de los Libros de Caxa y $\mathrm{Pa}$ nera de la abadía en los que se registran pagos de prometidos por posturas que no alcanzaron el remate correspondiente: en los arriendos de Palacino de 1588, 1596 y 1606, en el de Santovenia de 1625, en el de Villamor del mismo año y en el de Malateria de 1634 . AHN, Clero, Libro de Caxa, 5169, y Libros de Panera, 5190 y 5185. 


\section{CUADRO 6}

Comparación entre las rentas ingresadas por cinco beredades no vinculadas a un único lugar $y$ por nueve que si lo estaban

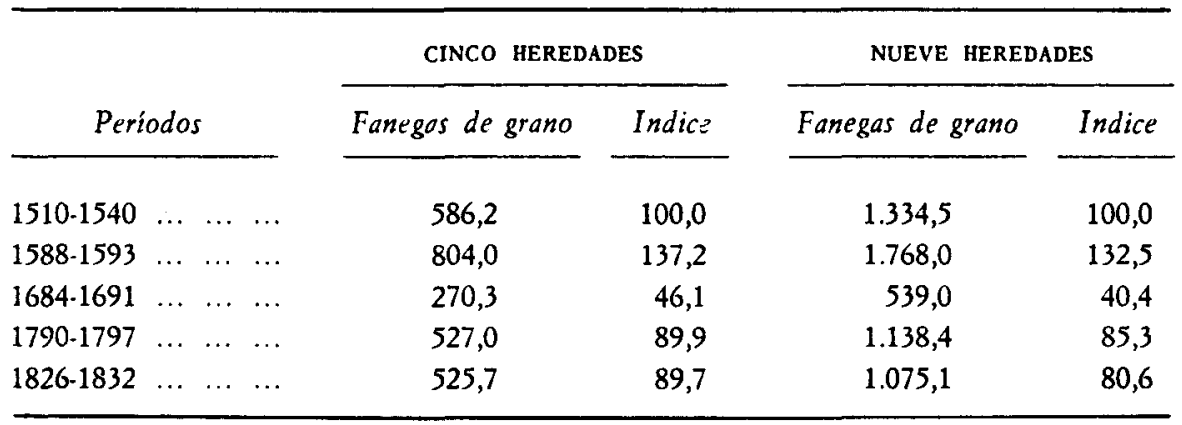

Fuentes: Las citadas en las notas 15,18 y 20.

Debe admitirse, por tanto, que los bernardos obtuvieron de su patrimonio territorial unas rentas ligeramente inferiores, por lo común, a las que habrían podido conseguir de acentuar la competencia entre sus arrendatarios. No obstante, conviene no caer en anacronismos y examinar otros aspectos de la cuestión: quizá deba apuntarse en el haber de tal estrategia la escasez de pleitos originados en impagos de rentas que se aprecia en la documentación monacal y, a pesar de la frecuente existencia de moratorias en los pagos, las pocas ocasiones en que los débitos hubieron de darse por fallidos e incobrables y la reducida cuantía de los mismos ${ }^{61}$.

En cualquier caso, difícilmente habrían podido hacer los monjes caso omiso del relieve que las comunidades aldeanas poseían en la zona y haber afrontado los costes que entrañaba tal opción. Aún más, a mi parecer, el consenso logrado a comienzos del siglo xvi en lo concerniente a la explotación de sus haciendas, constituyó un activo de capital importancia para la marcha de la economía monástica; la adaptación de ésta a las características de las explotaciones campesinas y el tácito respeto a la regla de arrendar, si pagó, a quién

"Un detallado seguimiento de los ingresos en especie por rentas de Sandoval arroja un monto total, para el período 1569.1835 , de 3.037 fanegas de granos perdonadas a locatarios deudores; estas condonaciones, por demás, aparecen concentradas en ciertos momentos, todos ellos muy significativos: 1613-1616, 1621-1622, 1630-1635, 1679-1680, 1694-1695, $1711,1805,1820,1823$ y 1835 . AHN, Clero, Libros de Panera, 5190, 5185, 5191 y 5192. 
arrendó, y luego a sus sucesores ${ }^{62}$, amén de no impedir a los cistercienses la consecución de notables ingresos, aseguró la sobrevivencia de la institución durante la Edad Moderna.

62 Esta norma, siempre implícita, remitía a una mentalidad muy arraigada en la sociedad rural leonesa, rara vez expresada con tan justas palabras como las empleadas por el llevador de la antigua granja monacal del Membrillar, cuando se dirigió al abad y a la comunidad demandando que se le aforase perpetuamente aquélla, nada menos que en julio de 1819:

«Angel Martinez residente y arrendatario de la Granja del Membrillar propia de este $\mathrm{M}{ }^{\circ}$ con la devida atencion, y respeto hace presente a V. Rma. y mas Monges de la misma que hace veinte años poco mas o menos la lleva en renta, y la llevaron sus maiores por mas de quarenta, empleando todos con. siderables afanes, y travajos para sostenerla, y sacar de su terreno ingrato el canon estipulado en los combenios; por cuia constancia en lavorearla ha adquirido una especie de havito en mirarla con el afecto, con que el Labrador estima siempre lo que cultiva con su sudor, y le seria sensible, que en cualquiera tiempo pasara a otras manos extrañas... en cuio caso y circunstancias cree muy ventajoso, tanto a los intereses del $\mathrm{M}^{\circ}$, como a los suios propios, y de su familia, que se le asegurase el usufructo de la citada Granja por medio de unas disposiciones y contratos permanentes que en nada perjudiquen al propietario y al colono...» (AHN, Clero, leg. 2753). 
LA RENTA DE LA TIERRA EN LEON DURANTE LA EDAD MODERNA

\section{APENDICE 1}

Rentas anuales ingresadas por la Abadia de Sandoval (1569-1835). Años de abril a abril; fanegas de todo pan

\begin{tabular}{|c|c|c|c|c|c|c|c|c|c|c|c|}
\hline$A \tilde{n o s}$ & Total & Años & Total & Años & Toral & Años & Total & Años & Total & Años & Total \\
\hline $1569-70$ & $3.805,0$ & 1619.20 & 2.650 .0 & $1669-70$ & $2.410,0$ & $1719-20$ & $2.216,7$ & $1769-70$ & $2.666,3$ & $1819-20$ & $2.771,0$ \\
\hline 1570.71 & $3.781,6$ & $1620-21$ & $2.640,4$ & $1670-7 !$ & $2.424,3$ & $1720-21$ & $2.216,7$ & $1770-71$ & $2.708,5$ & $1820-21$ & $2.515,8$ \\
\hline $1571-72$ & $3.807,6$ & $1621-22$ & $2.556,3$ & $1671-72$ & $2.439,3$ & $1721-22$ & 2.317 .6 & $1771-72$ & $2.708,0$ & $1821-22$ & \\
\hline $1572-73$ & $3.927,6$ & $1622-23$ & $2.847,6$ & $1672-72$ & $2.415,3$ & $1722-23$ & $2.301,6$ & $1772-73$ & $2.708,0$ & $1822-23$ & \\
\hline $1573-74$ & $3.897,3$ & $1623-24$ & $2.852,2$ & $1673-74$ & $2.387,3$ & $1723-24$ & $2.301,6$ & $1773-74$ & $2.714,2$ & $1823-24$ & $2.674,6$ \\
\hline $1574-75$ & $4.023,6$ & $1624-25$ & $2.797,8$ & $1674-75$ & $2.395,3$ & $1724-25$ & $2.301,6$ & $1774-75$ & $2.714,2$ & $1824-25$ & $2.664,3$ \\
\hline $1575-76$ & $4.007,8$ & $1625-26$ & $2.898,3$ & $1675-76$ & $2.365,0$ & 1725.26 & $2.301,6$ & $1775-76$ & $2.655,2$ & $1825-26$ & $2.776,7$ \\
\hline $1576-77$ & $4.003,8$ & 1626.27 & $2.964,3$ & $1676-77$ & $2.374,0$ & $1726-27$ & $2.319,5$ & $1776-77$ & $2.660,7$ & $1826-27$ & $2.776,7$ \\
\hline $1577-78$ & $4.008,7$ & $1627-28$ & $2.993,2$ & $1677-78$ & $2.374,0$ & $1727-28$ & $2.330,5$ & $1777-78$ & $2.660,7$ & $1827-28$ & $2.776,7$ \\
\hline $1578-79$ & $4.040,3$ & $1628-29$ & $3.096,3$ & $1678-79$ & $2,374,0$ & $1728-29$ & $2.330,0$ & $1778-79$ & 2.660 .7 & $1828-29$ & 2.776 .7 \\
\hline $1579-80$ & 4.007 .4 & $1629-30$ & $3.103,5$ & $1679-80$ & $2.374,0$ & $1729-30$ & $2.336,8$ & $1779-80$ & $2.678,0$ & $1829-30$ & $2.776,7$ \\
\hline $1580-81$ & $3.915,6$ & $1630-31$ & $3.054,3$ & $1680-81$ & $2.462,0$ & $1730-31$ & $2.415,3$ & $1780-81$ & $2.678,0$ & $1830-31$ & $2.776,7$ \\
\hline 1581-82 & $3.875,9$ & $1631-32$ & $3.056,2$ & $1681-82$ & $2.376,0$ & $1731-32$ & $2.392,7$ & $1781-82$ & $2.718,4$ & $1831-32$ & $2.776,7$ \\
\hline 1582.83 & $4.080,8$ & $1632-33$ & $3.096,1$ & $1682-83$ & $2.336,0$ & $1732-33$ & $2.407,9$ & $1782-83$ & 2. 723,7 & $1832-33$ & $2.771,0$ \\
\hline $1583-84$ & $4.033,7$ & $1633-34$ & $2.662,6$ & $1683-84$ & $2.344,0$ & $1733-34$ & $2.407,9$ & $1783-84$ & $2.723,7$ & $1833-34$ & $2.763,0$ \\
\hline $1584-85$ & $3.990,2$ & $1634-35$ & $2,875,5$ & $1684-85$ & $1.952,0$ & $1734-35$ & $2.420,4$ & $1784-85$ & $2.722,1$ & $1834-35$ & $2.763,0$ \\
\hline $1585-86$ & $4.341,4$ & $1635-36$ & $2.888,9$ & $1685-86$ & $1.910,0$ & $1735-36$ & $2.403,3$ & $1785-86$ & $2.752,3$ & 1835 & $2.746,4$ \\
\hline $1586-87$ & 4.539 .5 & $1636-37$ & $2.813,4$ & $1686-87$ & $1.761,0$ & $1736-37$ & $2.394,9$ & $1786-87$ & $2.816,9$ & & \\
\hline $1587-88$ & $4.536,0$ & $1637-38$ & $2.788,3$ & $1687-88$ & $1.745,9$ & 1737.38 & $2.394,9$ & $1787-88$ & $2.816,8$ & & \\
\hline $1588-89$ & $4.513,0$ & $1638-39$ & $2.798,3$ & 1688.89 & $1.679,3$ & $1738-39$ & $2.419,3$ & $1788-89$ & $2.836,6$ & & \\
\hline 1589.90 & $4.613,4$ & $1639-40$ & $2.822,5$ & $1689-90$ & $1.673,0$ & $1739-40$ & $2.411,5$ & $1789-90$ & $2.836,6$ & & \\
\hline $1590-91$ & $4.634,9$ & 1640.41 & $2.791,6$ & $1690-91$ & $1.959,4$ & $1740-4 t$ & 2.418 .3 & $1790-91$ & $3.034,7$ & & \\
\hline $1591-92$ & $4.580,9$ & $1641-42$ & $2.750,5$ & $1691-92$ & $1.940,7$ & $1741-42$ & $2.408,6$ & 1791.92 & $2.950,0$ & & \\
\hline $1592-93$ & $4.580,7$ & $1642-43$ & $2.836,5$ & $1692-93$ & $1.940,7$ & $1742-43$ & $2.408,6$ & $1792-93$ & $2.950,0$ & & \\
\hline $1593-94$ & $4.567,1$ & $1643-44$ & $2.823,4$ & $1693-94$ & $1.940,7$ & $1743-44$ & $2.512,9$ & $1793-94$ & $2.950,0$ & & \\
\hline $1594-95$ & $4.394,4$ & $1644-45$ & $2.865,9$ & $1694-95$ & $2.111,0$ & $1744-45$ & $2.525,1$ & 1794-95 & $2.950,0$ & & \\
\hline $1595-96$ & $4.509,6$ & $1645-46$ & $2.802,9$ & $1695-96$ & 2.224 .7 & $1745-46$ & $2.525,1$ & $1795-96$ & $2.947,0$ & & \\
\hline $1596-97$ & $4.530,5$ & $1646-47$ & $2.812,4$ & $1696-97$ & $2.220,7$ & $1746-47$ & $2.534,3$ & $1796-97$ & $2.950,0$ & & \\
\hline $1597-98$ & $4.396,3$ & $1647-48$ & $2.721,3$ & $1697-98$ & $2.220,7$ & $1747-48$ & $2.593,7$ & $1797-98$ & $2.948,0$ & & \\
\hline $1598-99$ & $4.336,8$ & $1648-49$ & $2.683,4$ & $1698-99$ & $2.342,7$ & $1748-49$ & $2.593,7$ & $1798-99$ & $2.943,3$ & & \\
\hline $1599-00$ & $3.989,1$ & $1649-50$ & $2.615,9$ & 1699.00 & $2.342,7$ & 1749.50 & $2.513,7$ & $1799-00$ & 2.947 .0 & & \\
\hline $1600-01$ & $3.838,6$ & $1650-51$ & $2.543,5$ & $1700-01$ & $2.340,0$ & $1750-51$ & $2.511,7$ & $1800-01$ & $2.950,0$ & & \\
\hline $1601-02$ & $3.483,4$ & $1651-52$ & $2.342,6$ & $1701-02$ & $2.312,0$ & $1751-52$ & $2.480,0$ & $1801-02$ & $2.950,0$ & & \\
\hline $1602-03$ & $3.622,5$ & $1652-53$ & $2.351,8$ & $1702-03$ & $2.232,0$ & $1752-53$ & $2.480,0$ & $1802-03$ & $2.949,9$ & & \\
\hline 1603-04 & $3.521,2$ & $1653-54$ & $2.390,5$ & $1703-04$ & $2.312,0$ & $1753-54$ & $2,473,2$ & 1803-04 & $2.943,5$ & & \\
\hline $1604-05$ & $3.518,2$ & $1654-55$ & $2.050,2$ & $1704-05$ & $2.326,5$ & $1754-55$ & $2.473,2$ & 1804-05 & $2.943,5$ & & \\
\hline $1605-06$ & $3.469,8$ & 1655 & $2.238,3$ & 170 & $2.326,5$ & $1755-56$ & $2.473,2$ & $1805-06$ & $2.943,5$ & & \\
\hline $1606-07$ & $3.505,6$ & $1656-57$ & $2.246,5$ & $170 \mathrm{~s}$ & $2.334,5$ & $1756-57$ & $2.553,5$ & 1806-07 & $2.895,3$ & & \\
\hline $1607-08$ & $3.481,5$ & $1657-58$ & $2.259,3$ & $1707-08$ & $2.298,5$ & $1757-58$ & $2.553,5$ & $1807-03$ & $2.699,0$ & & \\
\hline $1608-09$ & $3.456,8$ & $1658-59$ & $2.261,7$ & $1708-09$ & $2.296,9$ & $1758-59$ & $2.553,5$ & $1803-09$ & $2.694,3$ & & \\
\hline $1609-10$ & $3.127,7$ & $1659-60$ & $2.302,3$ & 1709 & $2.296,9$ & 1759.60 & $2.553,5$ & $1809-10$ & $1.512,7$ & & \\
\hline $1610-11$ & $3.194,7$ & $1660-61$ & $2.243,8$ & $1710-11$ & $2.296,9$ & $1760-61$ & $2.553,5$ & $1810-11$ & & & \\
\hline $1611-12$ & $3.091,4$ & $1661-62$ & $2.222,3$ & $1711-12$ & $2.296,9$ & $1761-62$ & $2.531,0$ & $1811-12$ & & & \\
\hline 1612.13 & $3.198,5$ & $1662-63$ & $2.305,4$ & $1712 \cdot 13$ & $2.266,9$ & $1762-63$ & $2.546,6$ & $1812-13$ & & & \\
\hline $1613-14$ & $3.151,0$ & $1663-64$ & $2.056,0$ & $1713-14$ & $2.264,5$ & $1763-64$ & $2.546,6$ & $1813-14$ & & & \\
\hline $1614-15$ & $3.012,2$ & $1664-65$ & $2.381,0$ & $1714-15$ & $2.264,5$ & $1764-65$ & $2.666,6$ & $1814-15$ & $2,554,7$ & & \\
\hline $1615-16$ & $3.022,3$ & $1665-66$ & $2.380,0$ & $1715-16$ & $2.262,8$ & $1765-66$ & $2.666,3$ & $1815-16$ & $2.606,2$ & & \\
\hline $1616-17$ & $2.854,8$ & $1666-67$ & $2.340,0$ & $1716-17$ & $2.247,0$ & $1766-67$ & $2.666,3$ & $1816-17$ & $2.826,7$ & & \\
\hline $1617-18$ & $2.855,8$ & $1667-68$ & $2.448,0$ & $1717-18$ & $2.223,0$ & $1767-68$ & $2.666,3$ & $1817-18$ & $2.766,5$ & & \\
\hline $1618-19$ & $2.815,6$ & $1668-69$ & $2.337,0$ & $1718-19$ & $2.208,7$ & $1768-69$ & $2.666,3$ & $1818-19$ & $2.767,0$ & & \\
\hline
\end{tabular}

Fuentes: AHN, Clero, Libros de Panera, 5190, 5185, 5191 y 5192. 


\section{BIBLIOGRAFIA CITADA}

Alvarez Vázquez, José Antonio (1984): «Evolución de los arrendamientos agrícolas de 1450 a 1850 en Zamora», en Congreso de Historia Rural. Siglos XV al XIX, Madrid, pp. 613-624.

- (1987): Rentas, precios y crédito en Zamora en el Antiguo Régimen, Zamora.

ANEs, Gonzalo (1970): Las crisis agrarias en la España moderna, Madrid.

Barrio Gozalo, Maximiliano (1982): Estudio socioeconómico de la iglesia de Segovia en el siglo XVIII, Segovia.

Canga Argüelles, José (1833): Diccionario de Hacienda, Madrid.

De Castro, Concepción (1987): El pan de Madrid. El abasto de las ciudades españolas del Antiguo Régimen, Madrid.

EsCrivá, José Luis, y Llopis, Enrique (1989): «La integración del mercado triguero en la Castilla la Vieja-León del Antiguo Régimen: avance y estancamiento», Hacienda Pública Española, 108-109 (homenaje a don Ramón Carande), pp. 117-131.

Fernández de Pinedo, Emiliano; Gil Novales, Alberto, y Derozier, Albert (1980): Centralismo, Ilustración y agonia del Antiguo Régimen (1715-1833), tomo VII de la Historia de España dirigida por Tuñón DE LaRA, Barcelona.

García Sanz, Angel (1977): Desarrollo y crisis del Antiguo Régimen en Castilla la Vieja. Economía y sociedad en tierras de Segovia de 1500 a 1814, Madrid.

- (1985): «El interior peninsular en el siglo xvm: un crecimiento moderado y tradicional», en Roberto FerNández (ed.), España en el siglo XVIII. Homenaje a Pierre Vilar, Barcelona.

- (1988): «Renta territorial y patrimonio de una casa nobiliaria en la Castilla del siglo XIX: los Marqueses de Lozoya, 1808-1896», resumen de dicha comunicación, presentada al Simposio de Historia Rural (siglos XVIII-XIX), celebrado en Santiago de Compostela.

López García, José Miguel (1986): La Abadia de la Santa Espina (1147-1835). Una aportación al estudio del señorio monástico en Castilla, tesis doctoral inédita, leída en la UAM en dicho año.

Madoz, Pascual (1845-1850): Diccionario Geográfico-Estadístico-Histórico de España y sus posesiones de Ultramar, Madrid (edición facsímil, Valladolid, 1983).

Marcos Martín, Alberto (1985): Economia, Sociedad, Pobreza en Castilla: Palencia, 15001814, 2 tomos, Palencia.

- (1988): «El crecimiento agrario castellano del siglo xviII en el movimiento de larga duración: ¿mito o realidad?", comunicación presentada al Seminario sobre "Agricultura e Ilustración en Españas, celebrado en Segovia.

Ouvrage collectif sous la direction de Jean-Pierre Amalric et Pierre Ponsot (1985): L'exploitation des grands domaines dans l'Espagne d'Ancien Régime, París.

Robledo Hernández, Ricardo (1984): La renta de la tierra en Castilla la Vieja y León (1836-1913), Madrid.

Rublo PÉrez, Laureano M. (1987): La Bañeza y su tierra, 1650-1850. Un modelo de sociedad rural leonesa (los bombres, los recursos y los comportamientos sociales), León.

Ruiz Torres, Pedro (1989): «Patrimonios y rentas de la nobleza en la España de finales del Antiguo Régimen», Hacienda Pública Española, 108-109 (homenaje a don Ramón Carande), pp. 293-310.

Sánchez Meco, Gregorio (1985): El Escorial y la Orden Jerónima. Análisis económicosocial de una comunidad religiosa, Madrid.

Yun Casalilla, Bartolomé (1985): «Producción agrícola en Tierra de Campos y Segovia: contrastes, similitudes y problemas en torno a la agricultura castellana en los siglos Xvi al xVIII", comunicación presentada al III Congreso de Historia Económica, Segovia.

- (1987): Sobre la transición al capitalismo en Castilla. Economia y Sociedad en Tierra de Campos (1500-1830), Salamanca. 